\title{
A preliminary study of development of the buccal apparatus in Pomacentridae (Teleostei, Perciformes)
}

\author{
B. FREDERICH* , E. PARMENTIER, P. VANDEWALLE \\ Laboratoire de Morphologie fonctionnelle et évolutive, Institut de Chimie (B6), Université de Liège, \\ B-4000 Liège, Belgium
}

\begin{abstract}
This study compares, in five species of Pomacentridae (Chromis viridis, Dascyllus flavicaudus, Chrysiptera glauca, Pomacentrus pavo, Plectroglyphidodon lacrymatus), the changes in cephalic skeletal structures between settling larvae and adults living on the reef. Variations were studied in the suspensorium, the opercle, the mandible, the premaxillary bone and the teeth. Comparisons of the feeding apparatus enabled two different types of feeding to be distinguished in adults: suction feeding and grazer sucking. Adult $C$. viridis and D. flavicaudus have a high suspensorium, a well-rounded mouth during jaw opening and caniniform teeth. These two species can be considered to be suction feeders. On the other hand, adult $C$. glauca, $P$. pavo and $P$. lacrymatus have less developed suspensoria, opercles and ascending process of the premaxillar, and present incisiform teeth. These three species appear to be grazer suckers. However, the larvae of all five species present an unimodal way of feeding, defined as ram-suction. Differences between larvae and adults appear clearly to be related to their ecology. The increasing variation presented in feeding apparatus during the settlement phase could be linked to diversification leading to occupancy of different ecological niches.
\end{abstract}

Keywords: Ecomorphology; larvae; metamorphosis; Pomacentridae.

\section{INTRODUCTION}

The Pomacentridae family, or damselfishes, includes more than 300 species living mainly in a coral reef environment (Allen, 1991; Nelson, 1994). Pomacentrids have been studied with reference to their systematics (Randall and Allen, 1977), to their ecology (Sale, 1976; Lobel, 1980; Montgomery, 1980; Williams, 1980; Meekan et al., 1995; Letourneur et al., 1997) and to their behaviour (Ormond et al., 1996; Fishelson, 1998). The first anatomical descriptions of their morphology were made by Ciardelli (1967) and Emery $(1973,1980)$. Potthoff et al. (1987) also conducted a

\footnotetext{
*Corresponding author; e-mail: bruno.frederich@ulg.ac.be
} 
study of the osteological development of Microspathodon chrysurus (Cuvier). More recently, some authors have been interested in the functional morphology (Galis and Snelderwaard, 1997; Gluckmann and Vandewalle, 1998; Gluckmann et al., 1999) and in the phylogeny (Tang, 2001; Jang-Liaw et al., 2002; Quenouille et al., 2004) of these fishes.

Most coral reef fish possess a complex life cycle involving a larval pelagic dispersal period and a benthic life period that starts after settlement (McCormick and Makey, 1997; Leis and McCormick, 2002). This shift in habitat is a crucial phase leading to behavioural changes that can coincide with morphological modifications (McCormick et al., 2002; Parmentier et al., 2004). The majority of damselfishes have a planktonic larval phase (Allen, 1991). This life period lasts 2 to 5 weeks, depending on the species (Wellington and Victor, 1989). The 'metamorphosis', generally coinciding with settlement (Leis and McCormick, 2002), mainly consists of acquisition of a bright colour and some morphological changes, such as modification of body shape (McCormick et al., 2002). Larvae are usually planktivorous, whereas juveniles and adults may have different diets (Drost et al., 1988) thus settlement phase can also correspond to changes in diet (Ciardelli, 1967; Letourneur et al., 1997). Moreover, in Microspathodon chrysurus, juveniles are mainly carnivorous, whereas adults are algal browsers (Ciardelli, 1967). This change in diet and lifestyle during development should result in morphological modifications to the food capture system (Liem, 1991, 1993; Wagemans and Vandewalle, 2001). To date, no study has described the transformation of larval cephalic skeletal structures into adult structures in Pomacentridae.

The aim of this study is to compare the buccal apparatus (premaxilla, suspensoria and opercules) of settling larvae and adults in five different pomacentrid species (fig. 1). These comparisons, realised in the framework of phylogenetic studies and ecological data, should provide insight into larval feature modification, and could bring an understanding of the adaptive radiation of this family on coral reefs.

Species were selected on the basis of two criteria: biology of the adults specially characterized by their habitat and diet (table 1), and Allen's classification (1991). Chromis viridis (Cuvier) and Dascyllus flavicaudus (Randall \& Allen) are Chrominae. Chrysiptera glauca (Cuvier), Pomacentrus pavo (Bloch) and Plectroglyphidodon lacrymatus (Quoy \& Guimard) are Pomacentrinae. According to Quenouille et al. (2004), Pomacentrinae can be divided into two clades: C. glauca and P. pavo belonging to one and P. lacrymatus to another.

\section{MATERIALS AND METHODS}

Specimens of each species were collected in Moorea (Society Islands, French Polynesia) in October 1997, July and August 1998, and November 1999. Adults were collected after the release of rotenone powder into the lagoon, or after exposure to a solution of quinaldine. During the same period, larvae were caught at night when they arrived on the reef crest. The net used $(1.5 \mathrm{~m}$ wide $\times 0.75 \mathrm{~m}$ height $\times$ 

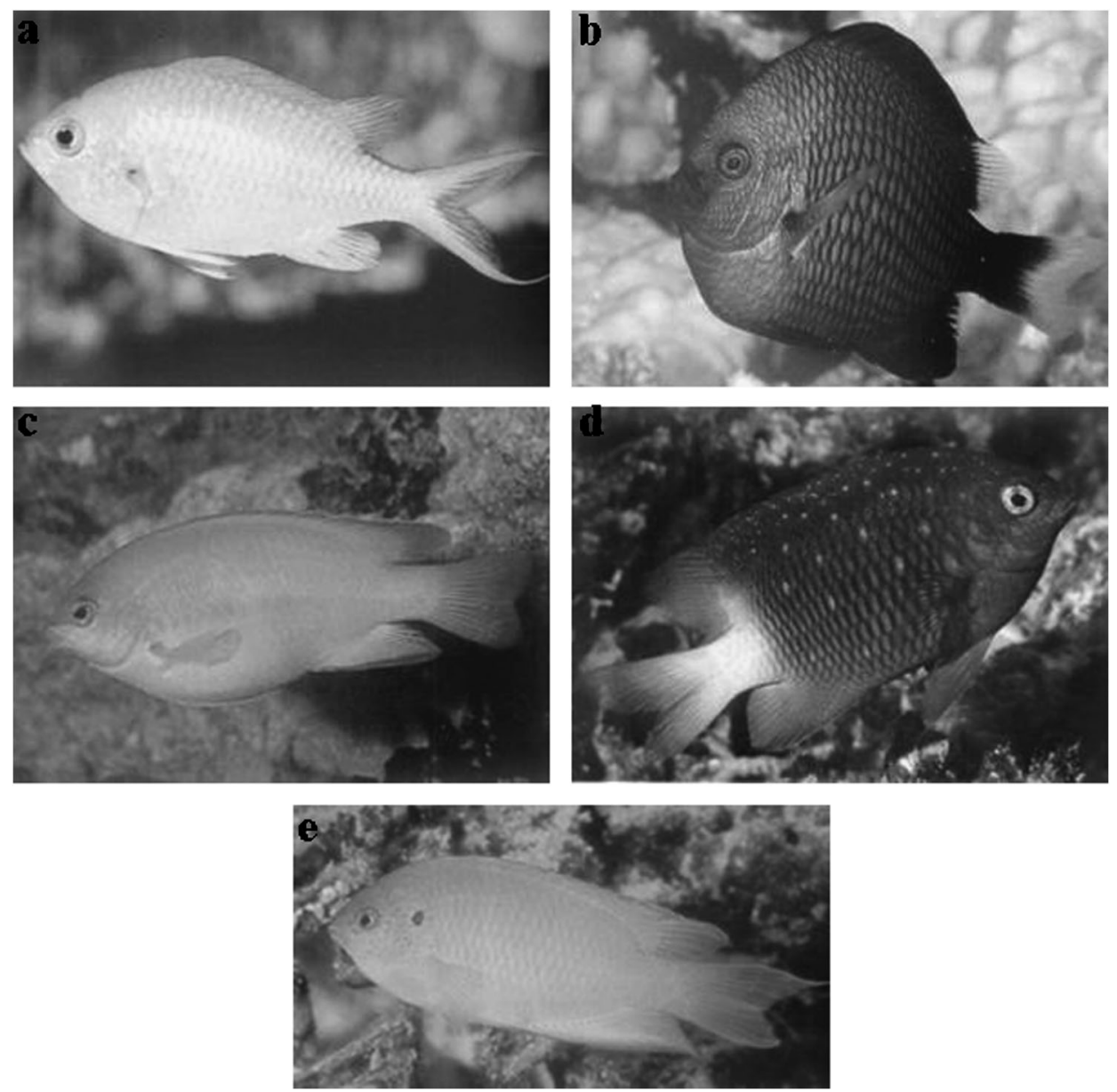

Figure 1. a, Chromis viridis; b, Dascyllus flavicaudus; c, Chrysiptera glauca; d, Plectroglyphidodon lacrymatus; e, Pomacentrus pavo (pictures from Allen, 1991).

$5 \mathrm{~m}$ length, $1 \mathrm{~mm}$ mesh) is similar to one used by Dufour et al. (1996). Samples were preserved in $10 \%$ formalin then transferred to $70 \%$ alcohol.

Anatomical descriptions are based on the observation of dissected specimens. Some of these specimens were stained with alizarin red S, following Taylor and Van Dyke's (1985) method. The following specimens were used: Chromis viridis: nine larvae (1 cm standard length, SL) and four adults (5-6 cm SL); Chrysiptera glauca: four larvae (1.5 cm SL) and four adults (5-7 cm SL); Dascyllus flavicaudus: two larvae (1.5 and $1.7 \mathrm{~cm} \mathrm{SL})$ and five adults $(5-8 \mathrm{~cm} \mathrm{SL}) ; P$. pavo: seven larvae $(1.5 \mathrm{~cm} \mathrm{SL})$ and five adults $(5-6 \mathrm{~cm} \mathrm{SL}) ;$ Plectroglyphidodon lacrymatus: two larvae (1.5 $\mathrm{cm} \mathrm{SL)} \mathrm{and} \mathrm{five} \mathrm{adults} \mathrm{(4-5} \mathrm{cm} \mathrm{SL).}$

The individuals observed were drawn with a Wild M5 binocular microscope coupled to a camera lucida. To facilitate comparison, we referred the neurocranium 
Table 1.

Biology of the five studied adult species.

\begin{tabular}{|c|c|c|c|c|}
\hline & Diet & Habitat & $\begin{array}{l}\text { Maximum } \\
\text { size } \\
(\mathrm{cm}, \mathrm{SL})\end{array}$ & References \\
\hline Chromis viridis & Zooplankton feeder & $\begin{array}{l}\text { Inshore and lagoon reefs; } \\
\text { closely associated with } \\
\text { branching corals, } \\
\text { especially Acropora }\end{array}$ & 7 & Allen, 1991 \\
\hline $\begin{array}{l}\text { Dascyllus } \\
\quad \text { flavicaudus }\end{array}$ & $\begin{array}{l}\text { Omnivorous feeding } \\
\text { largely on } \\
\text { zooplankton }\end{array}$ & Coral and rocky reefs & 9 & $\begin{array}{l}\text { Randall and } \\
\text { Allen, } 1977\end{array}$ \\
\hline Chrysiptera glauca & $\begin{array}{l}\text { Omnivorous feeding } \\
\text { largely on algae }\end{array}$ & $\begin{array}{l}\text { Shallow reefs exposed } \\
\text { to wave action }\end{array}$ & 8 & $\begin{array}{l}\text { Kuo and Shao, } \\
1991\end{array}$ \\
\hline Pomacentrus pavo & Omnivorous & $\begin{array}{l}\text { Sandy areas of lagoon } \\
\text { reefs, isolated patch reefs, } \\
\text { coral heads or rubble }\end{array}$ & 8.5 & Allen, 1991 \\
\hline $\begin{array}{l}\text { Plectroglyphidodon } \\
\text { lacrymatus }\end{array}$ & Herbivorous & $\begin{array}{l}\text { Lagoon and seaward reefs, } \\
\text { in areas with mixed } \\
\text { coral and rubble or dead } \\
\text { coral rocks }\end{array}$ & 8 & $\begin{array}{l}\text { Kuo and Shao, } \\
1991\end{array}$ \\
\hline
\end{tabular}

of larvae and adults to the same reference length. This was the flat projection of the distance between the former extremity of the ethmoïd area to the posterior extremity of the basioccipital, when the orbital portion of the parasphenoid was placed horizontally. The other studied structures were adjusted with respect to the neurocrania.

The teeth of the larvae and adults were dehydrated and underwent metallisation by Au-Pd pulverisation (Balzers SCD-30). Photographs were taken with a scanning electron microscope (Jeol, JSM840A) using an acceleration voltage of $19 \mathrm{kV}$.

Lower jaw-lever mechanics were investigated in larvae and adult fish of the five species. This method allows the comparison of efficiency of the jaw closing and opening systems (Wainwright and Richard, 1995). It is based on three measurements and two ratios. Distance from the mid-point of the articular-quadrate joint to the mid-point of the interopercular bone-angular joint corresponds to the jaw opening in-lever (line c; fig. 2b). The in-lever for jaw closing is the distance between the mid-point of the articular-quadrate joint to the point of insertion of the adductor mandibulae muscle on the articulo-angular. In Pomacentridae, the bundle A3 $\beta$ of the adductor mandibulae is the wider muscle inserting on the articulo-angular (Gluckmann et al., 1999). Its insertion on the medial face of the lower jaw, on the coronomeckelien, was chosen in this analysis (line b, fig. 2b). The jaw closing outlever is the distance between the mid-point of the articular-quadrate joint and the 

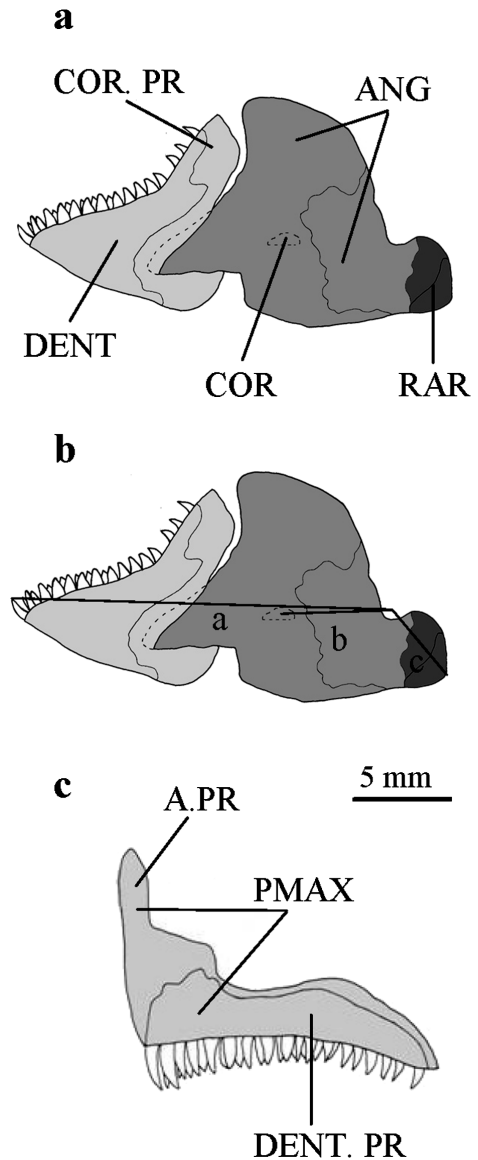

Figure 2. Pomacentrus pavo adult. a, lateral view of the mandible. $\mathbf{b}$, lateral view of the mandible illustrating the points of measurement for jaw lever arms. c, lateral view of the premaxillary bone. ANG, articulo-angular; A.PR, ascending process of the premaxilla; COR.PR, coronoïd process; COR, coronomeckelien; DENT, dentary; DENT.PR, dentigerous process; PMAX, premaxillary bone; RAR, retroarticular.

anterior tip of the dentary (line a; fig. 2b). Dimensionless ratios were calculated for the jaw opening and closing systems:

Jaw Opening Lever Ratio $(\mathrm{JO})=$ jaw opening in-lever/jaw closing out-lever.

Jaw Closing Lever Ratio (JC) = jaw closing in-lever/jaw closing out-lever.

\section{RESULTS}

\section{Morphology of the cephalic skeleton}

As the cranial osteology of some species of Pomacentridae has already been described by Ciardelli (1967) and Emery $(1973,1980)$, the description below mainly focuses on the differences among and between adults and larvae. 


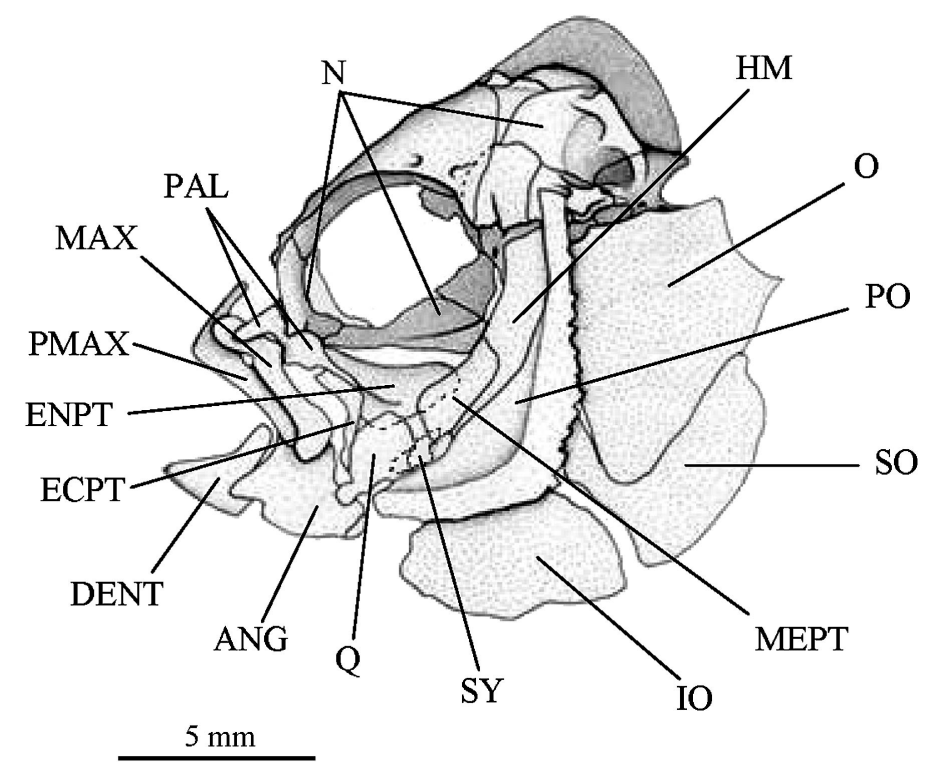

Figure 3. Pomacentrus pavo adult. Lateral view of the cranium. ANG, articulo-angular; DENT, dentary; ECPT, ectopterygoid; ENPT, entopterygoid; HM, hyomandibular; IO, interoperculum; MAX, maxillary; MEPT, metapterygoid; N, neurocranium; O, operculum; PAL, palatine; PMAX, premaxillary bone; PO, preoperculum; Q, quadrate; SO, suboperculum; SY, symplectic.

\section{Comparison of adults}

\section{Suspensorium and opercle (figs. 3, 4)}

The palatine of $P$. lacrymatus and D. flavicaudus is broader and larger than that of the other species. Its anterior process is clearly directed ventrally, whereas in C. viridis it is almost horizontal.

The upper edge of the suspensorium has a ' $U$ '-shaped curve formed by the dorsal edge of the hyomandibula, the metapterygoid, the entopterygoid and the palatine. This curve differs in the five species: it is less deep in P. lacrymatus and deeper in C. viridis, C. glauca and D. flavicaudus than in P. pavo. The hyomandibula of $C$. viridis, D. flavicaudus and $C$. glauca is more spindle-shaped, whereas that of P. lacrymatus is broader than that of P. pavo. Moreover, the hyomandibula of $C$. viridis is not as arched.

The preoperculum is only denticulated in $P$. pavo. The preoperculum of $P$. lacrymatus is broader than that of C. glauca, D. flavicaudus and P. pavo, while that of $C$. viridis is shorter.

In D. flavicaudus and C. glauca, the quadrate-mandible articulation and the ethmo-palatine joint are located on the same vertical line, whereas the first articulation is located slightly behind in P. lacrymatus, and is far behind in C. viridis and P. pavo. 
The unit formed by the operculum and the suboperculum in $C$. viridis and D. flavicaudus is higher and less broad than in P. pavo and C. glauca. The operculum of $P$. lacrymatus is the less high. The length of the interoperculum is a little higher in C. viridis, D. flavicaudus and C. glauca than in P. lacrymatus and P. pavo.

\section{Mandible (figs. 2; 5f-j)}

Chromis viridis has the longest and highest mandible. The same species also presents a large space between the coronoïd process of the dentary and the articuloangular. In D. flavicaudus and P. pavo, the dentary is proportionally smaller than the articulo-angular (fig. 5).

The dentary is highly curved in C. viridis and D. flavicaudus, less in P. pavo while practically not at all in C. glauca. The dentary in P. lacrymatus is, on the other hand, convex, at least in its anterior part. The position and orientation of quadratomandible articulation differ according to species. In P. pavo and P. lacrymatus, particularly, the joint with the quadrate is directed upwards and is almost vertical (fig. 5).

In $C$. viridis and D. flavicaudus, teeth are caniniform and distributed over almost the entire length of the dentary. They are arranged in two lines in the first species and in three lines in the second (fig. 6f, g). In D. flavicaudus, the anterior teeth of the external line are clearly larger than the others. All teeth are slightly bent towards the interior of the oral cavity. The dental organisation of $C$. glauca and P. pavo presents incisiform teeth distributed in two distinct lines (fig. 6h, i). In these two species, the union of the tips of teeth constitutes only one slicing edge. The dentary of $P$. lacrymatus carries only one line of very tight incisiform teeth (fig. $6 \mathrm{j}$ ). The shape of the incisiform teeth of P. lacrymatus differs from that of $P$. pavo and $C$. glauca. Indeed, the teeth present saggitaly a much broader base in $P$. lacrymatus. The slicing edge of this species is straight, whereas the extremity of the teeth in the two other species is more curved.

\section{Premaxilla (figs. 2c; 7f-j)}

The angle between the ascending process of the premaxilla and its dentigerous process differs according to species. It is less than $90^{\circ}$ in $C$. glauca and P. lacrymatus, practically equal to a right angle in $C$. viridis and $P$. pavo and a little greater than $90^{\circ}$ in $D$. flavicaudus. The premaxilla of $C$. viridis appears to be the thinnest and that of $P$. lacrymatus the most robust.

The dentigerous process of the premaxilla of $C$. viridis and D. flavicaudus is almost rectilinear, whereas that of $C$. glauca and $P$. lacrymatus is quite curved. In P. pavo, it presents an intermediate form.

In the five species, the set of teeth of the premaxilla are very similar to those of the dentary. 


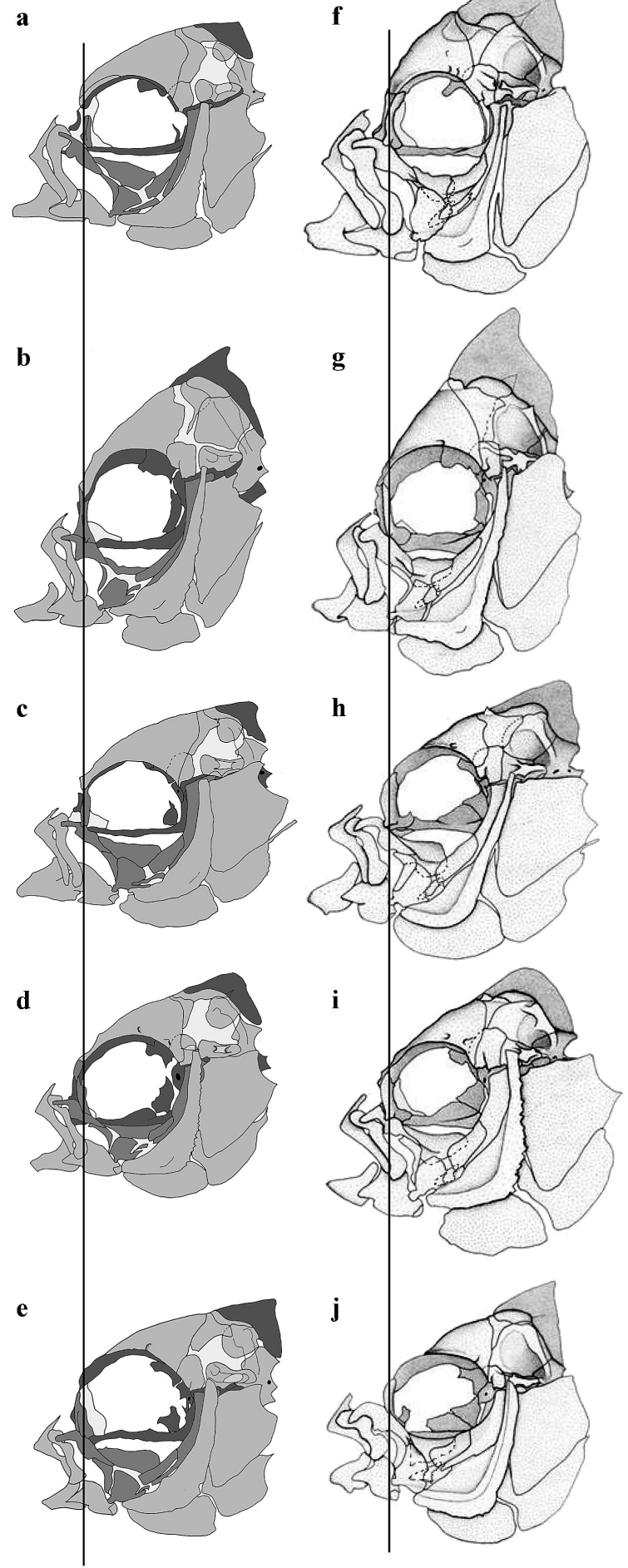




\section{Mouth opening and mouth closing (fig. 8)}

The five species can be divided into three groups according to the mouth opening and mouth closing function. When the mouth is closed, the position of the dentigerous process of the premaxillary bone is closer to the vertical in $C$. viridis and D. flavicaudus compared to the other three species. Conversely, in C. glauca and $P$. lacrymatus, the premaxillary bone is situated in a position such that its dentigerous process is most horizontal. Pomacentrus pavo has an intermediate position. In C. viridis and D. flavicaudus, at the time of mouth opening, the protraction is a downward and forward displacement of the premaxillary bone. In C. glauca and $P$. lacrymatus, this displacement is weaker but the premaxillary turns, bringing back the dentigerous process into a more vertical position. Mouth opening in P. pavo combines, at the same time, protraction of the premaxillary bone and pivoting.

\section{Comparison of larvae}

In the larvae of the five species, all components of the osseous cranium are present. However, the majority of these skeletal parts are not yet completely ossified and cartilaginous zones remain between the various osseous parts. The general shape of the cranium is very similar in $C$. viridis, $C$. glauca, P. lacrymatus and P. pavo. In D. flavicaudus, the cranium is higher and more ossified. The difference in height applies to the neurocranium as well as to the splanchnocranium. The larvae of C. viridis, which are smaller than the other species, have a less ossified cranium.

\section{Suspensorium and opercle (fig. 4)}

The suspensoria are very similar in the five species. In all species, the quadratemandible articulation is clearly located behind a vertical line passing through the articulation of the palatine with the neurocranium (fig. 4). The heads of articulation of the hyomandibula, for articulation with the neurocranium, are little developed in the five species. The symplectic of each species is rather thin. In $C$. viridis and C. glauca, the latter is particularly lengthened.

The shape of the three opercular bones differs relatively little from that of the adult. The unit formed by the opercle and the subopercle is narrower in $C$. viridis and $D$. flavicaudus than in the other species.

\section{Mandible and premaxilla (figs. 5, 7)}

The mandible is well formed. Among the larvae, P. lacrymatus has the shortest mandible. The principal difference between the mandible of the five species is in

Figure 4. Lateral view of the cranium in the five species. Left-hand column illustrates larvae and righthand column, adults. a, f, Chromis viridis; b, g, Dascyllus flavicaudus; $\mathbf{c}, \mathbf{h}$, Chrysiptera glauca; $\mathbf{d}$, $\mathbf{i}$, Pomacentrus pavo; e, j, Plectroglyphidodon lacrymatus. Each individual is aligned along a vertical line that passes through the ethmo-palatin articulation. 
a

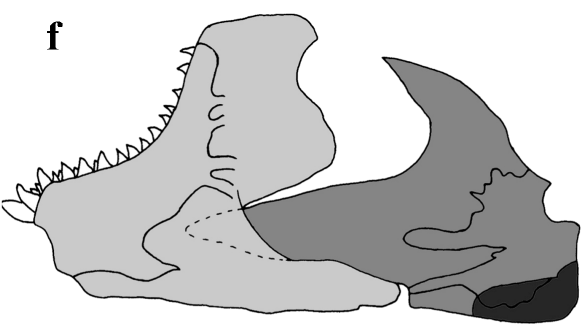

b

g

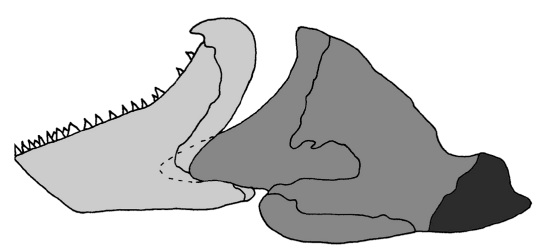

c

h
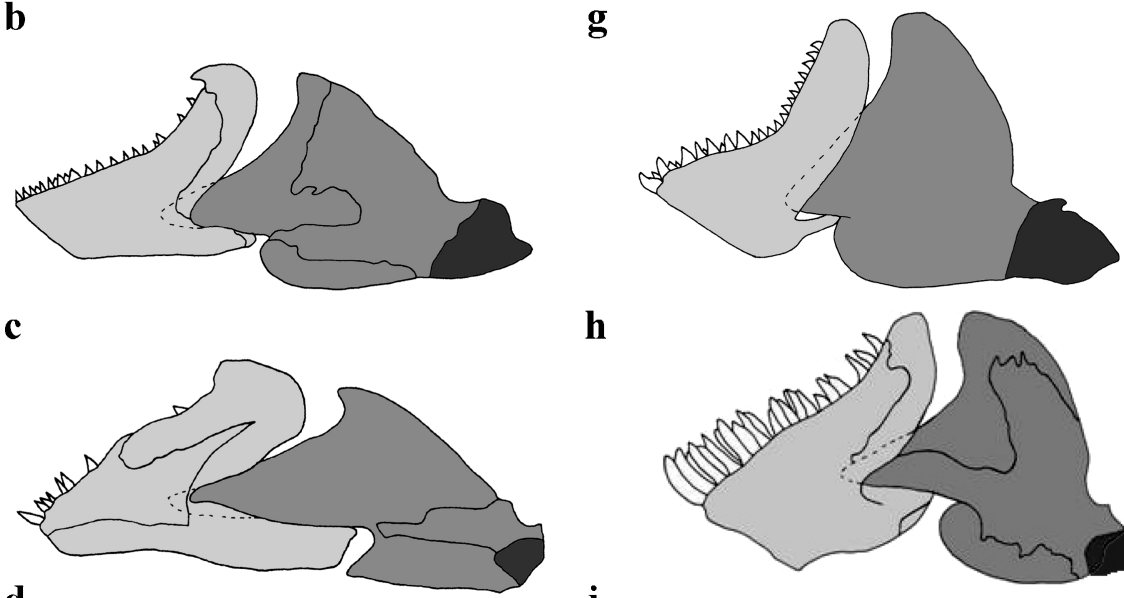

d

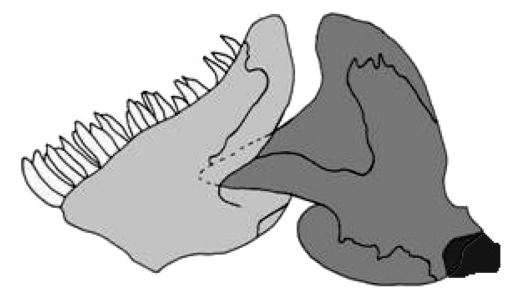

\section{i}

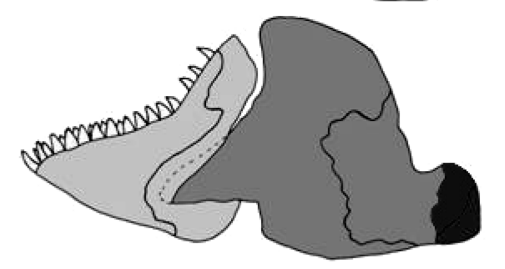

e

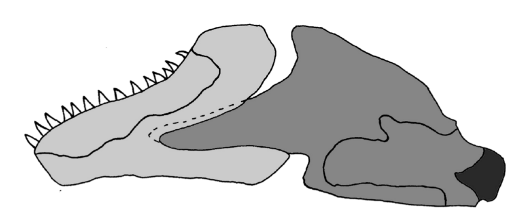

j
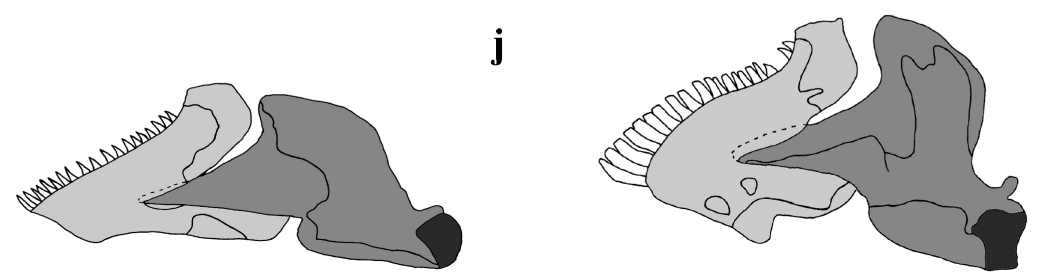

Figure 5. Lateral view of the left mandible. Left-hand column illustrates larvae and right-hand column, adults. a, f, Chromis viridis; b, g, Dascyllus flavicaudus; $\mathbf{c}, \mathbf{h}$, Chrysiptera glauca; d, i, Pomacentrus pavo; $\mathbf{e}, \mathbf{j}$, Plectroglyphidodon lacrymatus. The dentary is represent in light grey, the articulo-angular in intermediate grey and the retroarticular in black.

the location and orientation of the quadrato-mandible articulation. In $C$. viridis, the joint is directed upwards and in P. pavo, it is oriented more backwards. Dascyllus flavicaudus, C. glauca and P. lacrymatus show an intermediate position. 

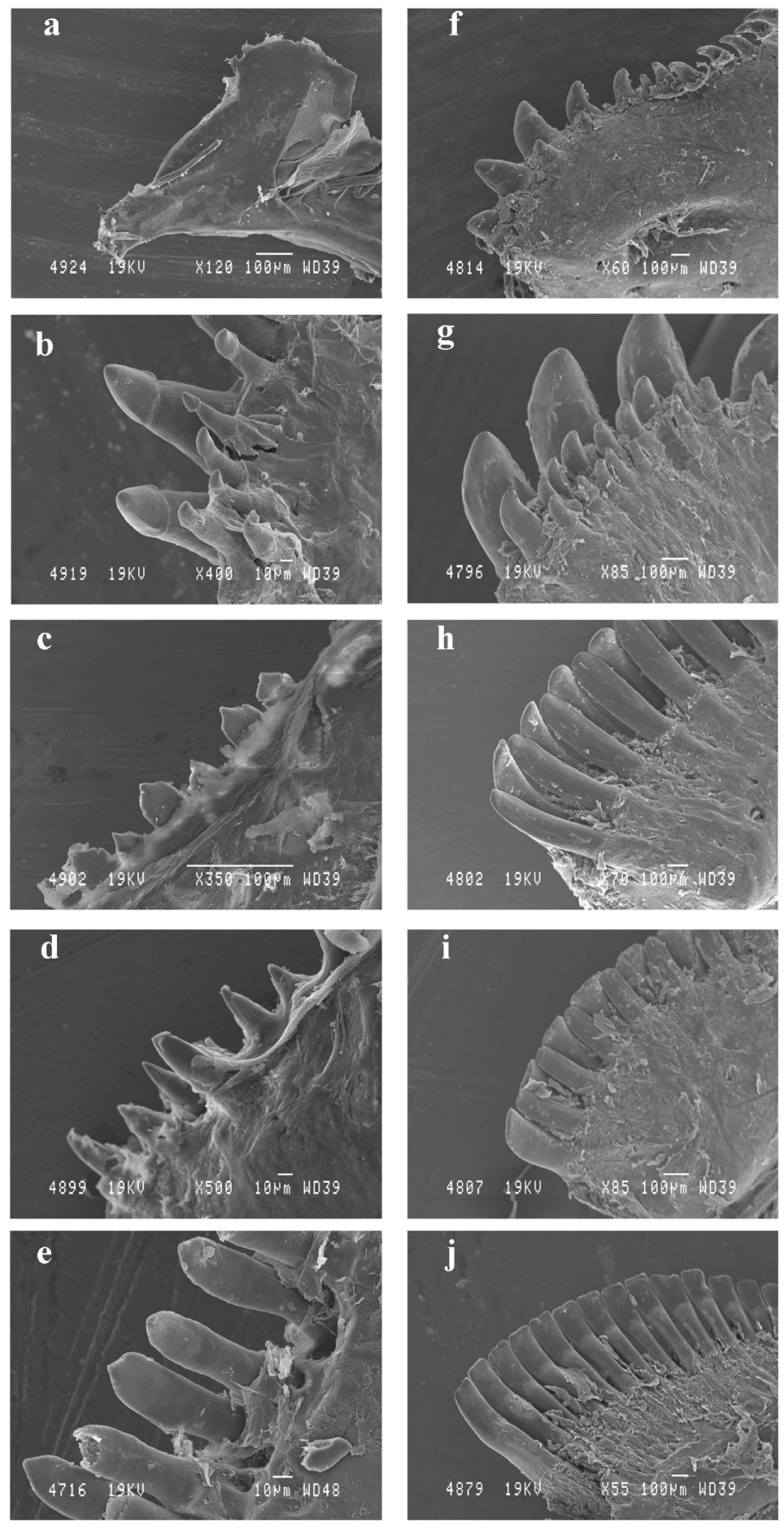

Figure 6. Comparison between the teeth of larvae $(\mathbf{a}, \mathbf{b}, \mathbf{c}, \mathbf{d}, \mathbf{e})$ and adults $(\mathbf{f}, \mathbf{g}, \mathbf{h}, \mathbf{i}, \mathbf{j})$; in Chromis viridis (a, f); Dascyllus flavicaudus (b, g); Chrysiptera glauca $(\mathbf{c}, \mathbf{h})$; Pomacentrus pavo (d, i); Plectroglyphidodon lacrymatus $(\mathbf{e}, \mathbf{j})$. Each photograph represents a view of the former part of the mandible, except for a, where the photograph represents a global view of the dentary. In $\mathbf{e}$, the holes in the jaw are the site of teeth bared during the manual cleaning of skeletal parts. 
$\mathbf{a}$

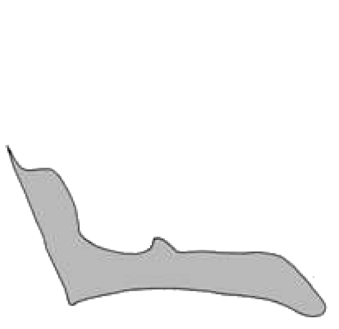

b

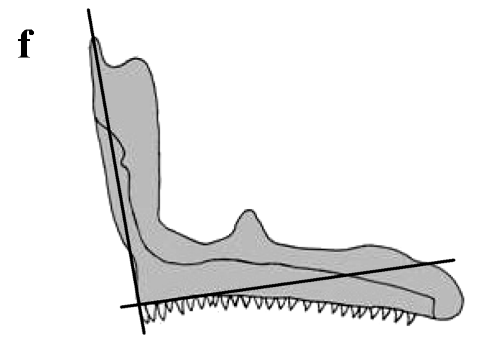

$\mathbf{g}$

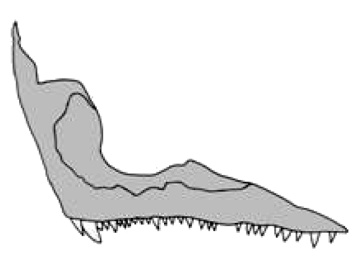

c

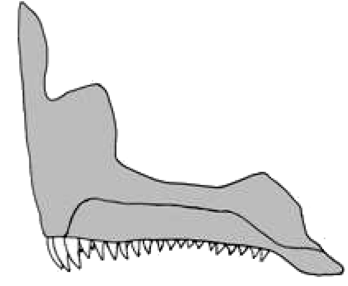

h

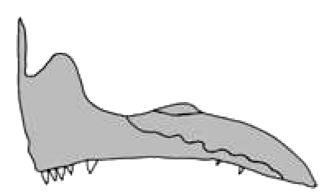

d

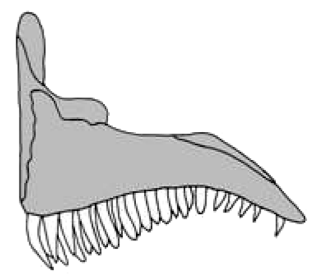

i
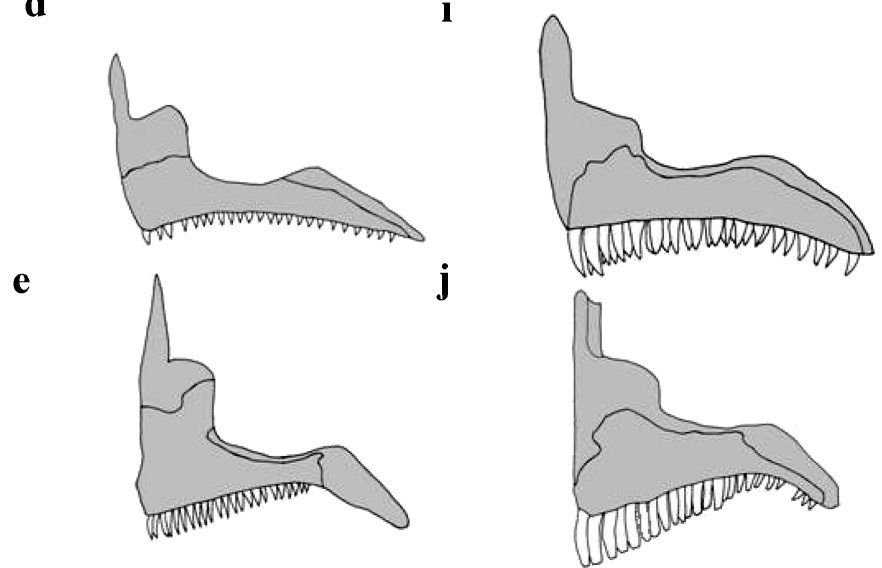

Figure 7. Lateral view of the left premaxillary bone. Left-hand column illustrates larvae and righthand column, adults. a, f, Chromis viridis; $\mathbf{b}, \mathbf{g}$, Dascyllus flavicaudus; $\mathbf{c}, \mathbf{h}$, Chrysiptera glauca; $\mathbf{d}$, $\mathbf{i}$, Pomacentrus pavo; $\mathbf{e}, \mathbf{j}$, Plectroglyphidodon lacrymatus. $\mathbf{f}$, lines illustrate how an angle is drawn between the ascending process and the dentigerous process of the premaxillary bone.

The angle between the ascending process and the dentigerous process of the premaxillae is greater than $90^{\circ}$, except in P. lacrymatus. The premaxilla of $C$. viridis are thinner, while those of $P$. lacrymatus are the shortest and the highest.

The premaxilla and the dentary bear no teeth in $C$. viridis (fig. 6a). In C. glauca, $P$. lacrymatus and $P$. pavo, teeth are organised in a simple line. In these species, 
the posterior part of the dentary and the premaxilla are toothless. Teeth are rather slender in P. pavo and are almost of tricuspid type in C. glauca and P. lacrymatus (fig. 6c-e). In D. flavicaudus the anterior part of the jaws carries two (almost three) lines of fine and slender teeth (fig. 6b). Teeth of the external line are larger and end in a small 'cap'; the posterior part carries a simple line of small conical teeth.

\section{Comparison between larvae and adults}

\section{Suspensorium and opercle (fig. 4)}

The unit 'suspensorium + opercle' becomes greater in adults. In the five species, the development of the opercle and the suspensorium is realised in height and/or width.

In $C$. viridis, the opercle and the suspensorium become broader and higher. The articulation condyle of the quadrate is clearly moved downwards in the adult. In D. flavicaudus, the heightening of the opercle is accompanied by a broadening of the suspensorium, which implies the same displacement of the quadrate articulation.

In $C$. glauca, the increase in the opercle is accompanied by a forward bending of the suspensorium without any change in the orientation of the hyomandibular articulation on the neurocranium. This new orientation of the suspensorium clearly moves the quadrate and mandible articulation forward.

In P. pavo, there is a widening posteriorly and ventrally for the suspensorium and the opercle. The articulation condyle of the quadrate only moves downwards. It is in P. lacrymatus where the changes seem the least substantial; the interopercle becomes broader and the articulation of the quadrate moves forwards.

Finally, in the five cases, the anterior process of the palatine inclines downwards.

\section{Mandible (fig. 5)}

In the five species, the mandible is higher in the adult than in the larva, which gives it a squatter and larger aspect. This aspect is clearly seen in $C$. glauca, P. lacrymatus and $P$. pavo, where the mandible of the adult appears proportionally shorter than that of the larva. The mandible stays about the same length proportionally in the adult and in the larva of D. flavicaudus. In C. viridis, there is a small relative lengthening of the mandible between the larvae and the adult, a lengthening that is, however, less important than the increase in height.

Height increase appears at the level of the dentary and its coronoïd process, as well as at the articulo-angular level. In the adult $P$. pavo, the curve of the toothed edge of the dentary becomes more marked. In D. flavicaudus, the toothed edge of the dentary of the adult is bent more than in the larva.

The dentary is clearly shorter in adults, except in the case of $C$. viridis. In adult $C$. glauca, the shortening of the mandible also seems to be due to the low development of the articulo-angular.

Articulation of the mandible with the quadrate is always deeper in adults than in larvae. The position and orientation of this articulation zone differ according 
to species and would vary during development (fig. 5). Indeed, the articulation is oriented more dorsally in the adults of $P$. pavo and P. lacrymatus and more ventrally in $C$. viridis.

\section{Premaxilla (fig. 7)}

In the five species, the ascending process of the premaxilla is longer in adults, but it is in $C$. viridis that this lengthening is most spectacular. Except for C. glauca, the dentigerous process is also stretched, especially in $C$. viridis.

The angle between the ascending and dentigerous processes is more acute in the adult than in the larvae of $C$. viridis, D. flavicaudus and C. glauca; this angle varies slightly in the other two species.

\section{Jaw lever mechanics}

The mechanical properties of the jaws are different among larvae, adults and between larvae and adults of each species (fig. 9).

The larvae of each species have a lower jaw opening ratio (JO) than do the adults (fig. 9a). Thus, there is a change from a mechanism with high velocity transmitting efficiency to a system that has better force transmission at the expense of speed. The magnitude of this change seems to be very similar in each species. In larvae and adults, the JO is the highest in D. flavicaudus and the lowest in C. viridis.

The jaw closing ratio (JC) increases between larvae and adults in each species, except in $C$. viridis, where it does not change (fig. 9b). This increase is the most important in $P$. pavo. In larvae and in adults, P. lacrymatus has the highest JC. Conversely, $C$. viridis has the smallest JC among the five species.

\section{DISCUSSION}

In spite of large specific diversity, damselfishes appear rather similar from their external morphology (Allen, 1991). However, a detailed examination of the cephalic skeleton reveals considerable differences among species.

Constructed of the same skeletal parts, differences are observed in the relative proportions of their components and in tooth morphology. Differences in relation to feeding apparatus can be related to species ecomorphology. Some authors (Block et al., 1991; Motta and Kotrschal, 1992; Norton et al., 1995) suggest that an ecomorphological approach may shed light on connections between the morphology of organisms and their lifestyle. This is because it brings together data related to the optimisation of the form-function complex in a given niche (Turingam, 1994; Westneat, 1995; Parmentier et al., 2000).

In fishes, diet intake is characterised by suction (Lauder, 1980). It is realised by two series of movements: (1) mouth opening followed by lowering of the pharyngeal floor, suspensoria spacing and, finally, the opercle abduction; and (2) mouth closing followed by raising of the pharyngeal floor and adduction of the suspensoria and 
the opercles. The succession of these movements generates water flow across the mouth, due to a depression set in the buccal and opercular cavities. Suction is more efficient when the buccal cavity is shaped like a large cone, with the mouth forming a small circular opening (Alexander, 1967; Liem, 1978; Lauder, 1980; Lauder and Lanyon, 1980; Vandewalle and Chardon, 1981; Drucker and Jencksen, 1991). This kind of cone is related to various characteristics, such as long ascending process of the premaxilla (Gosline, 1987) and/or high suspensoria and opercles (Liem, 1993).

Based on jaw apparatus morphology, Barel (1983) divides Cichlidae into 'biters' and 'suckers'. Epilithic algae scrapers, oral shelling molluscivores, insect pickers, scale eaters and fin biters are considered to be 'biters'. Piscivores and zooplanktivores are considered to be 'suckers'. However, this latter group could also be divided into ram feeders and suction feeders (Liem, 1993).

According to these features, $C$. viridis and D. flavicaudus show the greatest suction capacity and can be considered as suckers: the suspensorium is high and the protraction of the premaxillary bone provides a well-rounded mouth during jaw opening (fig. 8). Moreover, their caniniform teeth (fig. 6) are typical of species catching their food by suction (Emery, 1973; Barel, 1983; Motta, 1989). However, the presence of stronger caniniform teeth in D. flavicaudus and a well-developed mandible coronoïd process could relate to the catching of fixed prey or prey living on the substrate.

On the other hand, C. glauca, P. lacrymatus and P. pavo have less developed suspensoria, opercles and ascending process, and present incisiform teeth (fig. 6). These features appear to be related to their known diet; mainly herbivorous but also possibly feeding on organisms in water column and those fixed on the substrate (Allen, 1991; Kuo and Shao, 1991). In relation to this type of diet, the incisiform teeth would be used for grazing before suction (Barel, 1983; Liem, 1993). This assumption is reinforced by mouth shape during opening in C. glauca and $P$. lacrymatus. These fish do not have a very bent dentary and the dentigerous process of the premaxilla is curved. The resulting mouth shape allows correct occlusion for 'grazing'. However, their suction ability should be reduced due to a larger split mouth and no protraction of the premaxillary (fig. 8).

The three species, C. glauca, P. lacrymatus and P. pavo, all appear to be grazer suckers, but they also show some differences. Chrysiptera glauca and $P$. pavo have a double line of teeth entangled with each other, which seem to form a solid unit. The incisiform teeth of $P$. lacrymatus are arranged in a single line and look like a sharp blade.

Interestingly, the ecomorphological groups are also related to phylogeny (Tang, 2001; Jang-Liaw et al., 2002; Quenouille et al., 2004). The suckers C. viridis and $D$. flavicaudus are phylogenetically closely related. Of the grazer sucker species, C. glauca and P. pavo, which have a double line of incisiform teeth, are phylogenetically close, while P. lacrymatus is more distant. The morphological 

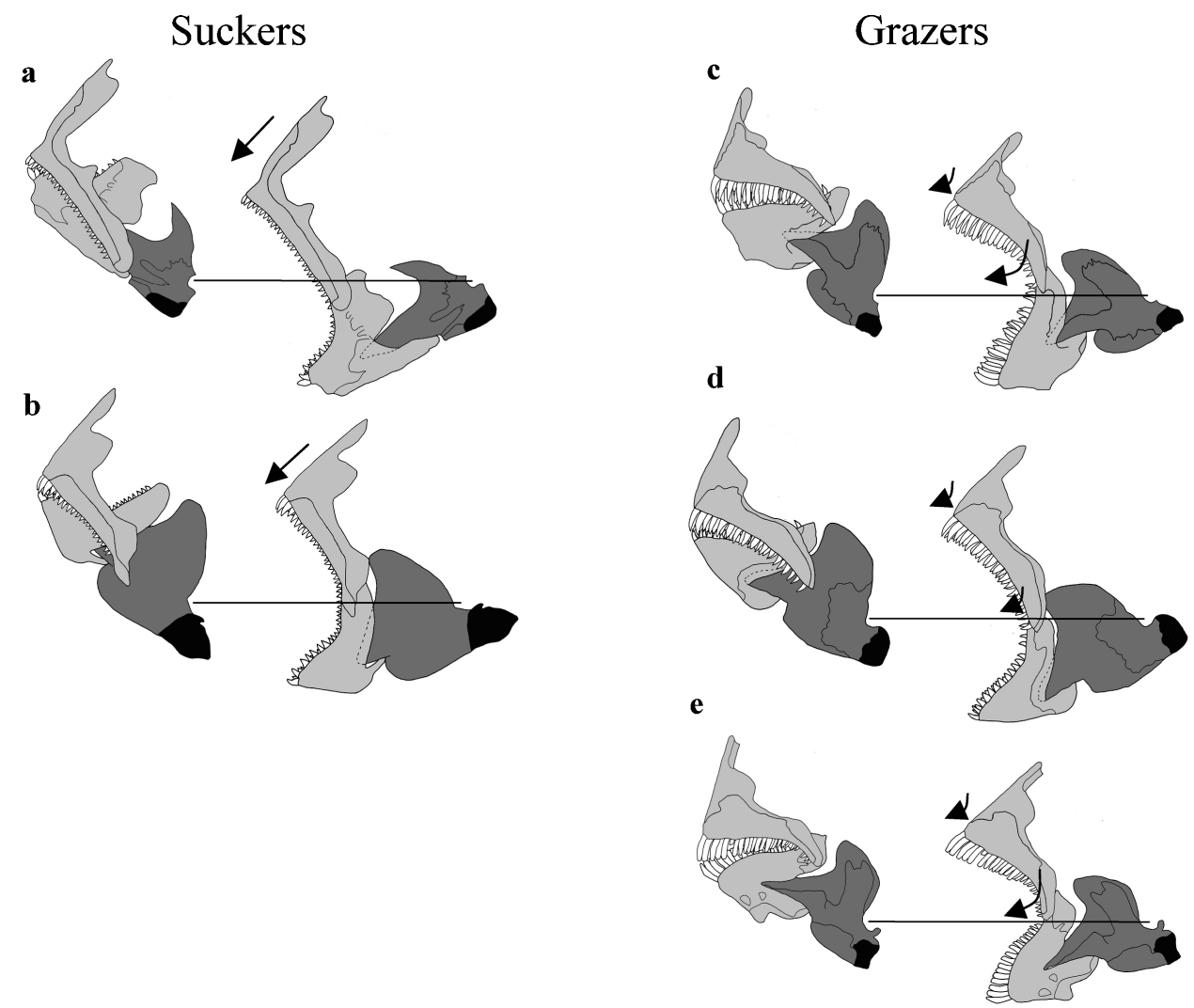

Figure 8. Lateral view of mouth opening and mouth closing in the five adult species. Mouth is composed of mandible and premaxillary bone. a, Chromis viridis; b, Dascyllus flavicaudus; c, Chrysiptera glauca; d, Pomacentrus pavo; e, Plectroglyphidodon lacrymatus. Horizontal lines illustrate that the articulation quadrate-mandible is fixed in the same position for mouth opening and mouth closing.

diversity of each group could correspond to the adaptive radiation of a common ancestor form which allows development in different ecological niches.

A link may be established between oral jaw morphology and feeding habit through lever arm mechanics of the lower jaw (Turingan, 1994; Wainwright and Richard, 1995). Assuming constant contractile properties of the muscles involved, a smaller jaw closing lever ratio will amplify the speed at which the muscles shorten during jaw adduction. In contrast, a larger jaw closing lever ratio indicates that the efficient translation of force by the muscles to the biting or crushing surface occurs at the expense of jaw closing speed. Crushing and biting species have higher jaw closing lever ratios than do suction-feeding species. The same consideration could be made about the jaw opening lever, where suction-feeding species have higher jaw opening lever ratios than do crushing and biting species. 

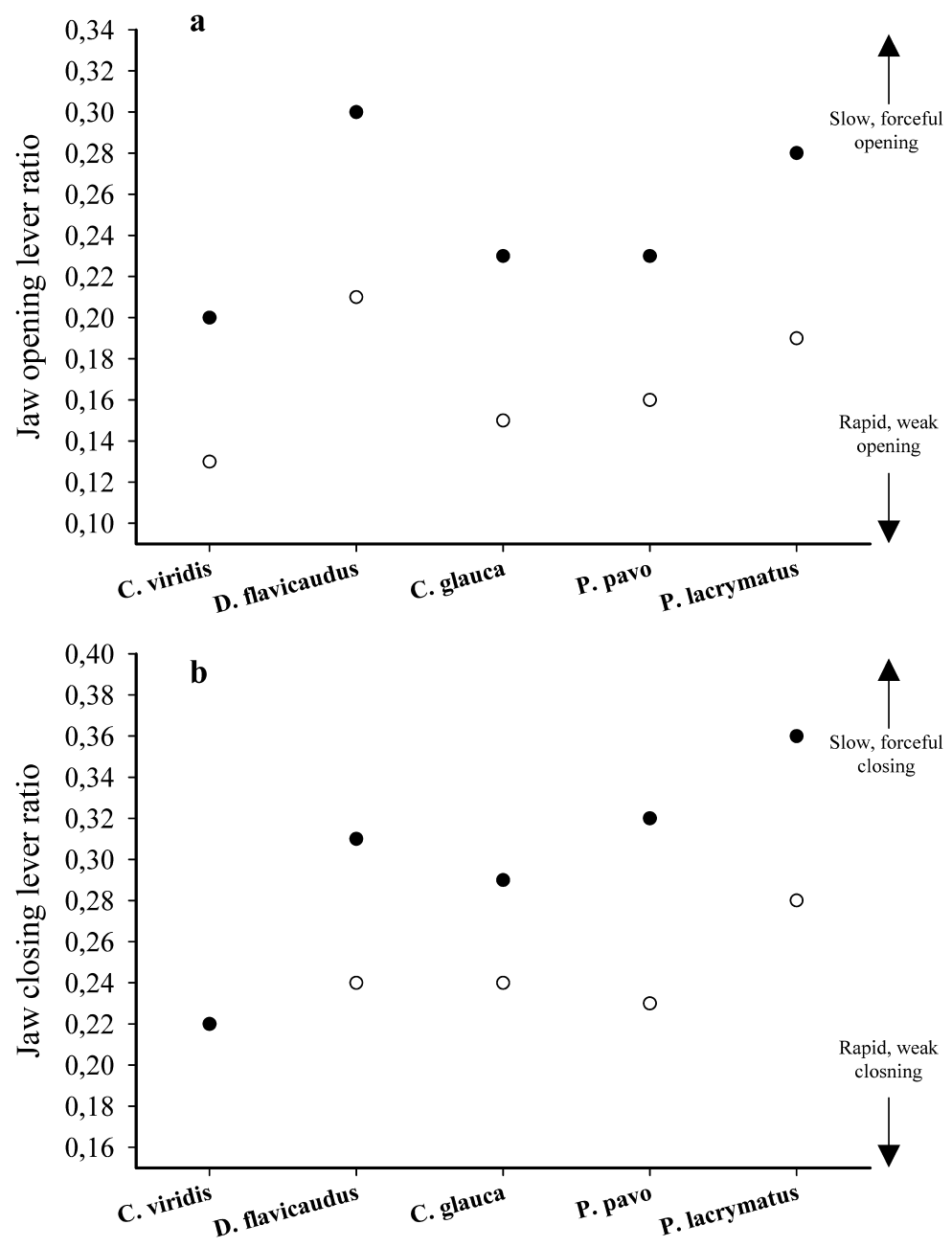

Figure 9. Plots of jaw-lever ratios for (a) mouth opening and (b) mouth closing systems. Black circles are adults and white circles are larvae. In $\mathbf{b}$, the jaw closing lever ratio of Chromis viridis is the same for larvae and adults.

Data dealing with the lever arm on 34 species of reef fishes (Wainwright and Richard, 1995) enables the division of fishes into two feeding modes: 'ram-suction feeders' and 'biters' (fig. 10), the latter including species that manipulate their prey (such as grazer, scraper, crusher and biter species). According to figure 10, C. viridis is a ram-suction feeder but all other species studied are considered to be grazers. These results confirm the assumed feeding mode of every species, except D. flavicaudus. This species is normally determined as a sucker, but it also has a high jaw closing lever ratio similar to that of $C$. glauca and $P$. pavo, which graze algae. This suggests a good capacity for seizure in addition to a great capacity for suction in this species. 


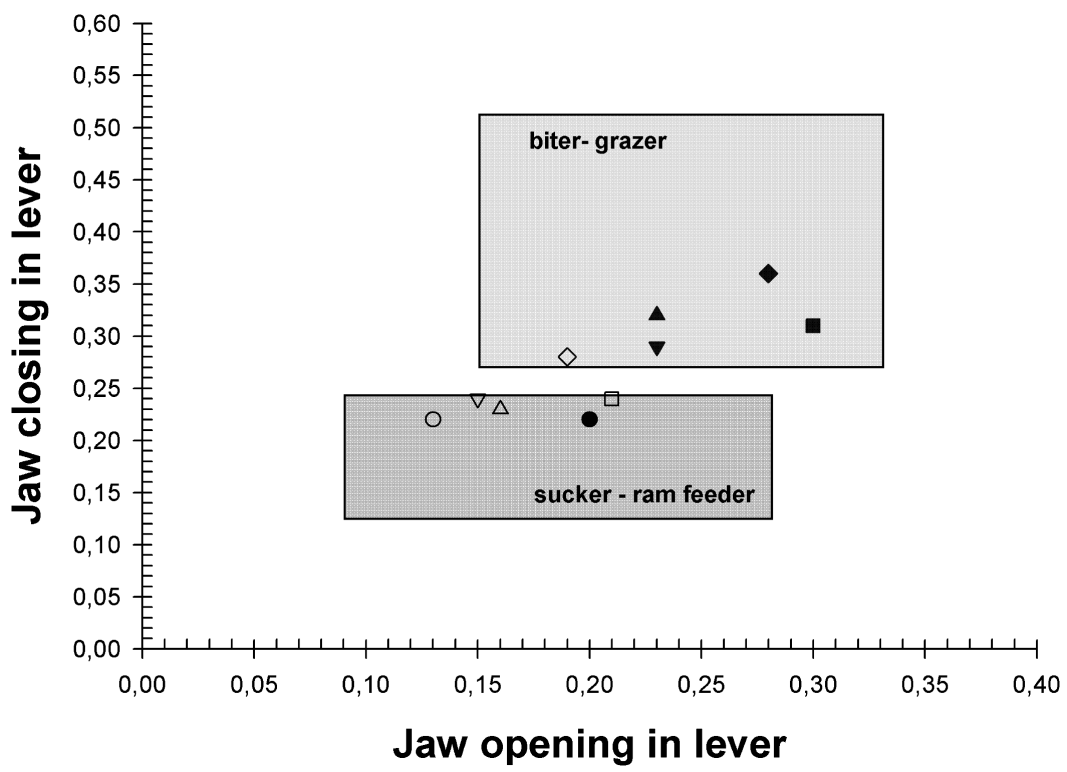

Figure 10. Plots of jaw opening in-lever and jaw closing in-lever. Symbols: circles = Chromis viridis; squares = Dascyllus flavicaudus; triangles downwards = Chrysiptera glauca ; triangles upwards $=$ Pomacentrus pavo; diamonds = Plectroglyphidodon lacrymatus. Black symbols = adults; white symbols $=$ larvae. Frames represent the range of lever ratio defining the two feeding mode: (1) 'bitergrazer', (2) 'sucker - ram feeder'. Maximum and minimum lever ratio scores permitting definition of frames are obtained from Wainwright and Richard (1995), in 34 species of Caribbean coral reef fishes.

\section{Comparison between larvae and adults with respect to their feeding apparatus}

Generally speaking, modifications observed during the development of larvae are concerned with the optimisation of the suction feeding system. These changes include: development in height and width of the suspensorium and opercle, advancement and/or descent of the quadrate-mandible articulation, shortening of the mandible, lengthening of the dentary coronoïd process and lengthening of the ascending process of the premaxillary bone. These modifications have also been observed during the development of other suction feeders (Wagemans and Vandewalle, 2001). On the other hand, in Carapidae, which feed mainly by seizure, the development of larvae appears related to jaw lengthening and backward displacement of the quadrate, resulting in a larger split mouth, where suction capacities are less developed (Parmentier, 2003).

Larval morphology and comparison of jaw opening and closing lever ratios (figs. $9,10)$ show that the different settling pomacentrids present common features. The larvae could be considered as ram-suction feeders, except for $P$. lacrymatus larvae (fig. 9). Indeed, this last species already presents the lever arms of a biter-grazer. Larval jaw lever ratios are different from those of adults. Moreover, the change 
observed during metamorphosis seems similar in each species, except in C. viridis, of which the adult acquires only a greater jaw opening in-lever (fig. 10).

The great similarity between the larvae could be due to at least two factors: phylogeny and ecomorphology. 1) Being phylogenetically closely-related, pomacentrids present a more common shape in their younger stages, with the main modifications in the adult shape emerging during development (Liem, 1991; Galis and Drucker, 1996). To guarantee the viability of the adult organism, these modifications should preferably appear at the end of development (Alberch et al., 1979), i.e., around the time that the pomacentrid reach the coral reefs. 2) The larvae live in the pelagic ocean and eat zooplankton (Leis and McCormick, 2002). Thus the shape of the larvae is a response to a common environment and a similar diet.

Moreover, the skull morphology of the pomacentrid larvae does not correspond to a suction-feeding apparatus. The backward position of the quadrate, the longer mandible, the shallow suspensorium and smaller opercle give to the larvae a cylindrical bucco-pharyngeal cavity, as is generally the case with ram-feeders (Liem, 1993). Larvae are also known to eat prey that is large in relation to their size (Drost et al., 1988; Osse, 1990; Baras et al., 2000; Shoji and Tanaka, 2001) and to have sustained swimming abilities (Leis, 2002). These factors are consistent with this mode of feeding.

However, the settling larvae also present morphological differences, highlighting that they are not all at the same level of development. This could be related to phylogeny or to different settlement behaviour: the larvae do not seem equal in terms of their aptitude to colonise their new environment (Leis and Carson-Ewart, 2002; Lecchini and Galzin, 2003). The magnitude and duration of the ecological shift occurring during settlement transition can be predicted from information on the extent of metamorphosis: species with a substantial metamorphosis up to the juvenile stage have a longer transition period than species that are well developed at settlement (McCormick and Makey, 1997; McCormick et al., 2002; Parmentier et al., 2004). From this point of view, D. flavicaudus exhibits morphology closer to that of the adult with a greater degree of ossification. In this case, D. flavicaudus would be ready to occupy the ecological niche of the adult more quickly than would the four other species.

\section{CONCLUSION}

Comparisons of the feeding apparatus enabled two different types of feeding to be distinguished in adults: suction feeding in $C$. viridis and D. flavicaudus and grazer sucking in $C$. glauca, $P$. pavo and $P$. lacrymatus. The observed morphological differences among the species are related to phylogeny to a certain extent. The morphological diversity of each group could correspond to the adaptive radiation of a common ancestor form. Conversely, the larvae of all five species present a unimodal way of feeding, defined as ram-suction. Differences between larvae and adults appear clearly to be related to their ecology. 


\section{ACKNOWLEDGEMENTS}

We thank N. Decloux and G. Goffinet for their help in scanning electron microscopy preparation and observation. We are grateful to $\mathrm{M}$. Chardon for his constructive comments. The authors thank P. Smith for her linguistic assistance. We acknowledge Gerry Allen and the publisher, Mergus Verlag, for their agreement to use their pictures of living pomacentrids illustrating this article. This work was supported by grant no. 2.4560 .96 from the Fonds National de la Recherche Scientifique of Belgium.

\section{REFERENCES}

Alberch, P., Gould, S.J., Oster, G.F. \& Wake, D.B. (1979) Size and shape in ontogeny and phylogeny. Paleobiology, 5, 296-317.

Alexander, R.Mc.N. (1967) The functions and mechanisms of the protrusible upper jaws of some acanthopterygian fish. J. Zool., 151, 43-64.

Allen, G.R. (1991) Damselfishes of the world. Publication of natural history and pets book, Germany.

Baras, E., Ndao, M., Maxi, M.Y.J., Jeandrain, D., Thomé, J.-P., Vandewalle, P. \& Mélard, C. (2000) Sibling cannibalism in dorada under experimental conditions. I. Ontogeny, dynamics, bioenergetics of cannibalism and prey size selectivity. J. Fish. Biol., 57, 1001-1020.

Barel, C.D.N. (1983) Towards a constructional morphology of cichlid fishes (Teleostei, Perciformes). Neth. J. Zool., 33(4), 357-424.

Block, W.M., Bennan, L.A. \& Gutierrez, R.J. (1991) Ecomorphological relationships of a guild of ground-foraging birds in northern California, USA. Oecologia, 87, 449-458.

Ciardelli, A. (1967) The anatomy of the feeding mechanism and the food habits of Microspathodon chrysurus (Pisces: Pomacentridae). Bull. Mar. Sci., 17, 843-883.

Drost, M.R., Osse, J.W. \& Muller, M. (1988) Prey capture by fish larvae, water flow patterns and the effect of escape movements of prey. Neth. J. Zool., 38(1), 23-45.

Drucker, E.G. \& Jencksen, J.S. (1991) Functional analysis of a specialized prey processing behavior: winnowing by Surgperches (Teleostei: Embiotocidae). J. Morphol., 210, 267-287.

Dufour, V., Riclet, E. \& Lo-Yat, A. (1996) Colonization of reef fishes at Moorea Island, French Polynesia: Temporal and spatial variation of the larva flux. N. Z. J. Mar. Freshw. Res., 47, 413422.

Emery, A.R. (1973) Comparative ecology and functional osteology of fourteen species of damselfish (Pisces: Pomacentridae) at Alligator Reef, Florida Keys. Bull. Mar. Sci., 23, 649-770.

Emery, A.R. (1980) The osteology of Lepidozygus tapeinosoma (Pisces: Pomacentridae). Bull. Mar. Sci., 30, 213-236.

Fishelson, L. (1998) Behaviour, socio-ecology and sexuality in damselfishes (Pomacentridae). Ital. J. Zool., 65 (Suppl.), 387-398.

Galis, F. \& Drucker, E.G. (1996) Pharyngeal biting mechanics in centrarchid and cichlid fishes: insights into a key evolutionary innovation. J. Evol. Biol., 9, 641-670.

Galis, F. \& Snelderwaard, P. (1997) A novel biting mechanism in damselfishes (Pomacentridae): the pushing up of the lower pharyngeal jaw by the pectoral girdle. Neth. J. Zool., 47(4), 405-410.

Gluckmann, I. \& Vandewalle, P. (1998) Morphofunctional analysis of the feeding apparatus in four Pomacentridae species: Dascyllus aruanus, Chromis retrofasciata, Chrysiptera biocellata and C. unimaculata. Ital. J. Zool., 65 (Suppl.), 421-424.

Gluckmann, I., Bussers, J.-C., Poulicek, M. \& Vandewalle, P. (1999) Preliminary study of the morphology of the head in Pomacentridae: adductor mandibulae organization in Dascyllus aruanus 
(Teleostei: Perciformes). In: B. Séret \& J.-Y. Sire (Eds.), Proc. 5th Indo-Pac. Fish Conf. Nouméa, 1997, pp. 89-97. Soc. Fr. Ichtyol., Paris.

Gosline, W.A. (1987) Jaw structures and movements in higher teleostean fishes. Jap. J. Ichth., 34(1), 21-32.

Jang-Liaw, N.-H., Tang, K.L., Hui, C.-F. \& Shao, K.-T. (2002) Molecular phylogeny of 48 species of damselfishes (Perciformes: Pomacentridae) using 12S mtDNA sequences. Mol. Phylogenet. Evol., $25,445-454$

Kuo, S.R. \& Shao, K.T. (1991) Feeding habits of damselfish (Pomacentridae) from the southern part of Taiwan. J. Fish. Soc. Taiwan, 18(3), 165-176.

Lauder, G.V. (1980) The suction feeding mechanism in sunfishes (Lepomis): an experimental analysis. J. Exp. Biol., 88, 49-72.

Lauder, G.V. \& Lanyon, L.E. (1980) Functional anatomy of feeding in the Bluegill sunfish Lepomis macrochirus: in vivo measurement of bone strain. J. Exp. Biol., 84, 33-55.

Lecchini, D. \& Galzin, R. (2003) Synthèse sur l'influence des processus pélagiques et benthiques, biotiques et abiotiques, stochastiques et déterministes, sur la dynamique de l'autorecrutement des poissons coralliens. Cybium, 27(3), 167-184.

Leis, J.M. (2002) Pacific coral-reef fishes: the implications of behaviour and ecology of larvae for biodiversity and conservation, and a reassessment of the open population paradigm. Environ. Biol. Fish., 65, 199-208.

Leis, J.M. \& McCormick, M.I. (2002) The biology, behaviour and ecology of the pelagic, larval stage of coral reef fishes. In: P.F. Sale (Ed.), Coral Reef Fishes: Dynamics and Diversity in a Complex Ecosystem, pp. 171-199. Academic Press, San Diego.

Leis, J.M. \& Carson-Ewart, B.M. (2002) In situ settlement behavior of damselfish (Pomacentridae) larvae. J. Fish. Biol., 61, 325-346.

Letourneur, Y., Galzin, R. \& Harmelin-Vivien, M. (1997) Temporal variations in the diet of the damselfish Stegastes nigricans (Lacepède) on a Réunion fringing reef. J. Exp. Mar. Biol. Ecol., 217, 1-18.

Liem, K.F. (1978) Modulatory multiplicity in the functional repertoire of the feeding mechanism in cichlid fishes. I. Piscivores. J. Morphol., 158(3), 323-360.

Liem, K.F. (1991) A functional approach to the development of the head of teleosts: implications on constructional morphology and constraints. In: N. Schmidt-Kittler \& K. Vogel (Eds.), Constructional Morphology and Evolution, pp. 231-249. Springer-Verlag, Berlin-Heidelberg.

Liem, K.F. (1993) Ecomorphology of the Teleostean skull. In: J. Hanken \& B.K. Hall (Eds.), The Skull, Vol. 3. Functional and Evolutionary Mechanisms, pp. 423-452. The University of Chicago Press, Chicago.

Lobel, P.S. (1980) Herbivory by damselfishes and their role in coral reef community ecology. Bull. Mar. Sci., 30, 273-289.

McCormick, M.I. \& Makey, L.J. (1997) Post-settlement transition in coral reef fishes: overlooked complexity in niche shifts. Mar. Ecol. Prog. Ser., 153, 247-257.

McCormick, M.I., Makey, L.J. \& Dufour, V. (2002) Comparative study of metamorphosis in tropical reef fishes. Mar. Biol., 141, 841-853.

Meekan, M.G., Steven, A.D.L. \& Fortin, M.J. (1995) Spatial patterns in the distribution of damselfishes on a fringing coral reef. Coral Reefs, 14, 151-161.

Montgomery, W.L. (1980) Comparative feeding ecology of two herbivorous damselfishes (Pomacentridae: Teleostei) from the Gulf of California, Mexico. J. Exp. Mar. Biol. Ecol., 47, 9-24.

Motta, P.J. (1989) Dentition patterns among Pacific and Western Atlantic butterflyfishes (Perciformes, Chaetodontidae): relationship to feeding ecology and evolutionary history. Environ. Biol. Fish., 25(1-3), 159-170.

Motta, P.J. \& Kotrschal, K.M. (1992) Correlative, experimental and comparative evolutionary approaches in ecomorphology. Neth. J. Zool., 42, 400-415.

Nelson, J.S. (1994) Fishes of the World. John Wiley \& Sons, New York. 
Norton, S.F., Luczkovich, J.J. \& Motta, P.J. (1995) The role of ecomorphological studies in the comparative biology of fishes. Environ. Biol. Fish., 44, 287-304.

Ormond, R.F.G., Roberts, J.M. \& Jan, R.-Q. (1996) Behavioural differences in microhabitat use by damselfishes (Pomacentridae): implications for reef fish biodiversity. J. Exp. Mar. Biol. Ecol., 202, 85-95.

Osse, J.W.M. (1990) Form changes in fish larvae in relation to changing demands of function. Neth. J. Zool., 40(1-2), 362-385.

Parmentier, E. (2003) Contribution à l'étude des relations entre des poissons de la famille des Carapidae et leurs hôtes invertébrés : une approche multidisciplinaire. Thesis, University of Liège.

Parmentier, E., Castro-Aguirre, J.L. \& Vandewalle, P. (2000) Morphological comparison of the buccal apparatus in two bivalve commensal Teleostei: Encheliophis dubius and Onuxodon fowleri (Carapidae, Ophidiiformes). Zoomorphology, 120, 29-37.

Parmentier, E., Lecchini, D., Lagardere, F. \& Vandewalle, P. (2004) Ontogenic and ecological control of metamorphosis onset in a carapid fish, Carapus homei: experimental evidence from vertebra and otolith comparisons. J. Exp. Zool., 301A, 617-628.

Potthoff, T., Kelley, S., Saksena, V., Moe, M. \& Young, F. (1987) Description of larval and juvenile yellowtail damselfish, Microspathodon chrysurus, Pomacentridae, and their osteological development. Bull. Mar. Sci., 40(2), 330-375.

Quenouille, B., Bermingham, E. \& Planes, S. (2004) Molecular systematics of damselfishes (Teleostei: Pomacentridae): Bayesian phylogenetic analyses of mitochondrial and nuclear DNA sequences. Mol. Phylogenet. Evol., 31(66), 66-88.

Randall, H.A. \& Allen, G.R. (1977) A revision of the damselfish genus Dascyllus (Pomacentridae) with the description of a new species. Rec. Aust. Mus., 31(9), 349-385.

Sale, P.F. (1976) The effect of territorial adult pomacentrid fishes on the recruitment and survival of juveniles on patches of coral rubble. J. Exp. Mar. Biol. Ecol., 24, 297-306.

Shoji, J. \& Tanaka, M. (2001) Strong piscivory of Japanese Spanish mackerel larvae from their first feeding. J. Fish. Biol., 59, 1682-1685.

Tang, K.L. (2001) Phylogenetic relationships among damselfishes (Teleostei: Pomacentridae) as determined by mitochondrial DNA data. Copeia, 3, 591-601.

Taylor, W.R. \& Van Dyke, G.C. (1985) Revised procedure for staining and clearing small fishes and other vertebrates for bone and cartilage study. Cybium, 9(2), 107-121.

Turingan, R.G. (1994) Ecomorphological relationships among Caribbean tetraodontiform fishes. $J$. Zool., 223, 493-521.

Vandewalle, P. \& Chardon, M. (1981) Réflexions sur les rapports entre forme, structure et fonction chez des poissons de la famille des Cyprinidae. Cybium, 5(3), 67-70.

Wagemans, F. \& Vandewalle, P. (2001) Development of the bony skull in common sole: brief survey of morpho-functional aspects of ossification sequence. J. Fish. Biol., 59, 1350-1369.

Wainwright, P.C. \& Richard, B.A. (1995) Predicting patterns of prey use from morphology of fishes. Environ. Biol. Fish., 44, 97-113.

Wellington, G.M. \& Victor, B.C. (1989) Planktonic larval duration of one hundred species of Pacific and Atlantic damselfishes (Pomacentridae). Mar. Biol., 101, 557-567.

Westneat, M.W. (1995) Phylogenetic systematics and biomechanics in ecomorphology. Environ; Biol. Fish., 44, 263-283.

Williams, D.Mc.B. (1980) Dynamics of the pomacentrid community on small patch reefs in One Tree Lagoon (Great Barrier Reef). Bull. Mar. Sci., 30, 159-170. 